NBER WORKING PAPER SERIES

\title{
IMMIGRATION AND ECONOMIC GROWTH
}

\author{
George J. Borjas \\ Working Paper 25836 \\ http://www.nber.org/papers/w25836
NATIONAL BUREAU OF ECONOMIC RESEARCH
1050 Massachusetts Avenue
Cambridge, MA 02138
May 2019

This paper was first presented at the "Prospects for Economic Growth Conference" held at Rice University's Baker Institute in December 2018 and will be published in Prospects for Economic Growth in the United States, edited by John W. Diamond and George R. Zodrow (Oxford University Press). The views expressed herein are those of the author and do not necessarily reflect the views of the National Bureau of Economic Research.

NBER working papers are circulated for discussion and comment purposes. They have not been peer-reviewed or been subject to the review by the NBER Board of Directors that accompanies official NBER publications.

(C) 2019 by George J. Borjas. All rights reserved. Short sections of text, not to exceed two paragraphs, may be quoted without explicit permission provided that full credit, including (C) notice, is given to the source. 
Immigration and Economic Growth

George J. Borjas

NBER Working Paper No. 25836

May 2019

JEL No. J6,O4

\begin{abstract}
$\underline{\text { ABSTRACT }}$
Immigration is sometimes claimed to be a key contributor to economic growth. Few academic studies, however, examine the direct link between immigration and growth. And the evidence on the outcomes that the literature does examine (such as the impact on wages or government receipts and expenditures) is far too mixed to allow unequivocal inferences. This paper surveys what we know about the relationship between immigration and growth. The canonical Solow model implies that a one-time supply shock will not have any impact on steady-state per-capita income, while a continuous supply shock will permanently reduce per-capita income. The observed relationship between immigration and growth obviously depends on many variables, including the skill composition of immigrants, the rate of assimilation, the distributional labor market consequences, the size of the immigration surplus, the potential human capital externalities, and the long-term fiscal impact. Despite the methodological disagreements about how to measure all of these effects, there is a consensus on one important point: Immigration has a more beneficial impact on growth when the immigrant flow is composed of high-skill workers.
\end{abstract}

George J. Borjas

Harvard Kennedy School

79 JFK Street

Cambridge, MA 02138

and NBER

gborjas@harvard.edu 


\section{Immigration and Economic Growth}

\section{George J. Borjas*}

From 1990 to 2014, U.S. economic growth would have been 15 percentage points lower without the benefit of migration.

-Citi Research (2018)

There's a way for President Trump to boost the economy by four percent, but he probably won't like it...For every 1 percent increase in U.S. population made of immigrants, GDP rises 1.15 percent. So a simple way to get to Trump's 4 percent GDP bump? Take in about 8 million net immigrants per year.

-ProPublica (2017)

\section{Introduction}

There has been a worldwide surge in international migration in recent decades. In the U.S. context, the immigrant share of the population almost tripled from a historic low of 4.7 percent in 1970 to 13.7 percent by 2017 .

It is sometimes claimed that the immigration surge has been a key contributor to economic growth, and that an even larger number of immigrants would increase our national wealth even more-although these claims tend to appear in reports produced by think tanks, policy advocates, and business associations. In fact, few academic studies document the direct link between immigration and growth. And the evidence on the outcomes that the studies do examine (such as the impact on wages, employment, and government receipts and expenditures) is far too mixed and unsettled to justify blanket

* Robert W. Scrivner Professor of Economics and Social Policy, Harvard Kennedy School; and Research Associate, National Bureau of Economic Research. This paper was first presented at the "Prospects for Economic Growth Conference" held at Rice University's Baker Institute in December 2018 and will be published in Prospects for Economic Growth in the United States, edited by John W. Diamond and George R. Zodrow (Oxford University Press). 
statements that immigration accounts for a substantial part of economic growth (or, conversely, that it does not contribute to economic growth at all).

Despite the relative scarcity of credible research on the link between immigration and growth, there is no doubt that immigrants contribute significantly to aggregate output. In 2016, 16.6 percent of workers in the U.S. labor market were foreign-born. The large immigrant presence in the workforce inevitably implies that foreign-born labor was directly responsible for a sizable fraction of GDP. And, by definition, the immigration surge must have led to a correspondingly large increase in GDP. It is far less clear, however, that the immigrant supply shock necessarily increased per-capita income.

This paper presents a theoretical and empirical survey of what it is that we know about the link between immigration and economic growth. The canonical Solow growth model has striking implications about what happens as the economy adjusts to supply shocks. A one-time supply shock increases output and decreases per-capita income in the short run. As the economy adjusts, there will be relatively rapid "catch-up" growth. In the end, however, per-capita income ends up in exactly the same steady state that would have been observed had there been no immigration. In contrast, a permanent increase in the rate of growth of the workforce due to a persistent immigrant flow will lead to increased output but at a permanently lower per-capita income.

I use these insights to frame the discussion of what economics has to say about immigration and growth. The link obviously depends on many variables, including the skills that immigrants bring to the country; the rate at which immigrants become more productive (which is typically thought of as "economic assimilation"); the impact of immigration on the employment opportunities of native workers; the impact immigrants 
have on the total income accruing to the pre-existing population (i.e., the "immigration surplus"); and the fiscal impact of immigration, as measured by a comparison of the taxes immigrants pay with the cost of the services they receive. The net impact of immigration on economic growth will depend on the direction and magnitude of all of these effects.

Despite the uncertainty about the measurement of each of these effects, there is a consensus on one important point: Immigration has a more beneficial impact when the immigrant influx is composed of high-skill workers. In the end, there is little doubt about the type of immigration policy a country should pursue if it wished to use immigration as a tool to spur growth: Admit high-skill immigrants. (Although the literature is totally silent on just how many high-skill immigrants should be admitted). There is, however, an important normative question that economics—and economists—cannot answer: Should spurring economic growth be the sole objective of immigration policy?

\section{Immigration in the Solow Model}

It is useful to fix ideas by illustrating the link between immigration and growth in the canonical Solow model (Barro and Sala-i-Martin, 1999). The model is summarized by:

$$
\begin{gathered}
Y_{t}=\left(K_{t}\right)^{\alpha}\left(A_{t} L_{t}\right)^{1-\alpha}, \\
\dot{K}_{t}=s Y_{t}-\delta K_{t}, \\
L_{t}=L_{0} e^{g t} \\
A_{t}=A_{0} e^{\eta t}
\end{gathered}
$$

Equation (1) gives the linear homogeneous Cobb-Douglas production function where $Y_{t}$ denotes output at time $t ; K_{t}$ the capital stock; and $\left(A_{t} L_{t}\right)$ the number of efficiency units in the labor market, with $A_{t}$ being the efficiency parameter and $L_{t}$ the number of workers. Equation (2) gives the equation of motion for the capital stock, with constant savings rate $s$ 
and depreciation rate $\delta$. Finally, equations (3) and (4) specify that the number of workers grows at rate $g$ and the efficiency of a worker grows at rate $\eta$.

Let $k_{t}$ denote the "effective" capital-labor ratio, $K_{t} / A_{t} L_{t}$. Income per efficiency unit (which is not observed) can be written as:

$$
y_{t}=\frac{Y_{t}}{A_{t} L_{t}}=k_{t}^{\alpha},
$$

while the observed per-capita income $\bar{y}_{t}$ is:

$$
\bar{y}_{t}=\frac{Y_{t}}{L_{t}}=A_{t} k_{t}^{\alpha}
$$

Finally, the wage $(w)$ and the rental rate of capital $(r)$ at time $t$ are given by the marginal productivity conditions:

$$
\begin{gathered}
w_{t}=(1-\alpha) A_{t} k_{t}^{\alpha}, \\
r_{t}=\alpha k_{t}^{\alpha-1} .
\end{gathered}
$$

Equation (2) can be rewritten in terms of the effective capital-labor ratio as $\dot{k}=$ $s y_{t}-(\delta+\eta+g) k_{t}$. This implies that the steady-state effective capital-labor ratio is:

$$
k^{*}=\left(\frac{s}{\delta+\eta+g}\right)^{\frac{1}{1-\alpha}} .
$$

Note that the rental rate of capital is constant in the steady state. If labor efficiency is increasing at rate $\eta>0$, however, both the wage and per-capita income will also increase at rate $\eta$ in the steady state.

Suppose the economy is in steady state, and immigration produces a one-time increase in the size of the workforce. Consider the special case where the size of the workforce was constant prior to the supply shock $(g=0)$. A one-time influx of immigrants who are perfect substitutes with pre-existing workers can then be modeled as a simple 
shift in $L$. The one-time supply shock produces an immediate drop in the effective capitallabor ratio (which in turn, increases the rental rate of capital and reduces the wage). It follows that the immediate impact on output and per-capita income are given by:

$$
\begin{gathered}
\frac{\partial Y_{t}}{\partial L}=(1-\alpha) \bar{y}_{t}>0, \\
\frac{\partial \bar{y}_{t}}{\partial L}=\alpha A_{t} k_{t}^{\alpha-1} \frac{\partial k_{t}}{\partial L}<0,
\end{gathered}
$$

The one-time supply shock trivially increases GDP (more workers produce more output). But the supply shock reduces per-capita income in the short run.

This short-run drop is attenuated as the economy adjusts to the larger workforce. The decline in the capital-labor ratio increases the rate of return to capital, inducing an increase in the capital stock. As equation (9) shows, however, the steady state effective capital-labor ratio does not depend on the size of the workforce. As a result, the one-time supply shock does not change the steady state level of per-capita income:

$$
\frac{\partial \bar{y}^{*}}{\partial L}=0
$$

Once the steady-state equilibrium is reestablished, the economy has a larger GDP, and percapita income continues to grow at the same rate $\eta \cdot{ }^{1}$

The model can also be used to analyze the impact of a continuous supply shock, which can be modeled as an increase in $g$, the rate of growth in the size of the workforce. This persistent shock has long-term consequences. Equation (9) implies that it reduces the steady state level of the effective capital-labor ratio $\left(\partial k^{*} / \partial g<0\right)$. It then follows that:

${ }^{1}$ The transitional dynamics after the one-time shock are interesting. Per-capita income was growing at a constant rate of $\eta$ prior to the shock. After the shock (and before the economy is re-equilibrated), the growth rate increases to $(\eta+\alpha \dot{k} / k)$, where $\dot{k}>0$. The growth spurt is short-lived. It only reflects that the shock immediately reduced per-capita income and the economy is reverting to the original steady state. 


$$
\frac{\partial \bar{y}^{*}}{\partial g}=\alpha A_{t} k_{t}^{\alpha-1} \frac{\partial k^{*}}{\partial g}<0
$$

In short, a persistent immigrant flow permanently reduces per-capita income.

An augmented version of the Solow model (Mankiw, Romer, and Weil, 1992; Dolado, Goria, and Ichino, 1994) can be used to derive the implications if immigrants also increase the country's human capital stock $(H)$. The linear homogeneous production function in the augmented model is typically written as:

$$
Y_{t}=\left(K_{t}\right)^{\alpha}\left(H_{t}\right)^{\beta}\left(A_{t} L_{t}\right)^{1-\alpha-\beta},
$$

and the equations of motion for the physical and human capital stocks are:

$$
\begin{gathered}
\dot{K}_{t}=s_{K} Y_{t}-\delta K_{t}, \\
\dot{H}_{t}=s_{H} Y_{t}-\delta H_{t}+M_{t} \pi\left(\frac{H_{t}}{L_{t}}\right),
\end{gathered}
$$

where $s_{K}$ and $s_{H}$ are the (constant) investment rates for physical and human capital, respectively; the depreciation rate $\delta$ is assumed to be the same for both types of capital; $M_{t}$ is the net number of immigrants; and $\pi$ measures the relative contribution of an immigrant to the human capital stock. The immigrant is as skilled as a pre-existing worker if $\pi=1$.

The change in the number of workers is $\dot{L_{t}}=g L_{t}+M_{t}$. Suppose that the number of immigrants increases at the same rate as the native population, so that the net migration rate $m=M_{t} / L_{t}$ is constant. The workforce then grows at constant rate $(g+m)$, and the equations of motion for the effective capital-labor ratios are given by:

$$
\begin{gathered}
\dot{k}=s_{K} y_{t}-[\delta+\eta+g+m] k_{t}, \\
\dot{h}=s_{H} y_{t}-[\delta+\eta+g+(1-\pi) m] h_{t} .
\end{gathered}
$$

The steady state is defined by $\dot{k}=0$ and $\dot{h}=0$. The effective capital/labor ratios in the steady state are: 


$$
\begin{aligned}
k^{*} & =\left(\frac{s_{K}}{\delta+\eta+g+m}\right)^{\frac{1-\beta}{1-\alpha-\beta}}\left(\frac{s_{H}}{\delta+\eta+g+(1-\pi) m}\right)^{\frac{\beta}{1-\alpha-\beta}} \\
h^{*} & =\left(\frac{s_{K}}{\delta+\eta+g+m}\right)^{\frac{\alpha}{1-\alpha-\beta}}\left(\frac{s_{H}}{\delta+\eta+g+(1-\pi) m}\right)^{\frac{1-\alpha}{1-\alpha-\beta}} .
\end{aligned}
$$

The steady state capital-labor ratios in equations (19) and (20) are constant. As a result, effective per-capita income (given by $y=k^{\alpha} h^{\beta}$ ) will also be constant. In contrast, actual per-capita income $\left(\bar{y}=A k^{\alpha} h^{\beta}\right)$ will still grow at a rate of $\eta$ (as was the case in the simpler version of the Solow model).

Equations (19)-(20) imply that immigration alters steady-state per-capita income:

$$
\frac{\partial \log \bar{y}^{*}}{\partial m}=-\frac{\alpha}{(1-\alpha-\beta) C}-\frac{\beta}{(1-\alpha-\beta) D}[1-\pi]
$$

where $C=[\delta+\eta+g+m]$; and $D=[\delta+\eta+g+(1-\pi) m]>0$. Per-capita income will certainly decline if $\pi \leq 1$ (a case relevant for the recent U.S. context with high numbers of low-skill immigrants). In fact, the diminishing marginal productivity of labor implies that per-capita income might fall even if immigrants are relatively more skilled (with $\pi$ being slightly above 1). Equation (21) shows that immigration can spur long-term growth only if the influx is very skilled, with sufficiently high values of $\pi$.

An important lesson from this brief overview of the Solow model is that persistent immigration will often reduce per-capita income in the steady state, particularly when the immigrants are perfect substitutes or less skilled than the natives. Immigration may spur long-term growth only if the supply shock is composed of very highly skilled workers. In fact, such a supply shock could increase per-capita incomes by far more than the model suggests if the immigrants also produce human capital externalities that permanently increase the productivity of native workers. 


\section{Immigration and GDP: Evidence}

Despite the contentious policy debate over immigration, only a handful of studies study the empirical link between immigration and long-term growth. ${ }^{2}$ Hence, it is useful to begin by illustrating the relationship between GDP and immigration trends in the United States.

Each decennial census since 1850 reports the number of foreign-born persons, allowing the calculation of net immigration in each decade. Define the net migration rate in the decade between years $t$ and $t+10$ as the net number of immigrants arriving in that decade divided by the population at time $t$. For expositional convenience, I multiply the net migration rate by 100 so that it gives the number of new immigrants per 100 persons. As

Figure 1 shows, there have been periods of very high and of very low immigration. Between 1900 and 1910 and between 1990 and 2000, the net migration rate was about 4 persons per decade. In contrast, the net migration rate was negative between 1930 and 1970 .

The two panels of the figure also show the decadal rate of change in (real) GDP and in per-capita GDP. It is visually obvious that the simple correlation implied by the historical record does not suggest that there was more rapid economic growth during those periods of high immigration. In fact, the slope of a regression that relates the rate of change in GDP

2 See Boubtane, Dumont, and Rault (2016), Dolado, Goria, and Ichino (1994) and Kane and Rutledge (2018). Related work by Peri (2012) correlates immigration with total factor productivity (TFP), where TFP is a residual from a regression that links state-level GDP to the size of the workforce and measures of the capital stock. It is particularly difficult to interpret the correlation between TFP and immigration as much depends on the regression specification, and on what exactly is included and left out of the first-stage regression. 
to the net migration rate is 0.008 (with a standard error of 0.014 ), while the respective coefficient in the per-capita growth regression is $-0.010(0.012)$.

Obviously, these weak correlations do not prove the absence of a causal link between immigration and growth. There are far too many other factors that influence the evolution of economic output and Figure 1 does not control for any of these factors. It is possible, however, to examine the causal relationship by linking trends in state-level economic growth and immigration during the 1960-2017 period.

Specifically, I use the decadal census data to calculate the immigrant share in the workforce of each state $r$ at time $t$ and estimate the regression model: ${ }^{3}$

$$
\log y_{r t}=\theta_{r}+\theta_{t}+\beta p_{r t}+\gamma h_{r t}+\epsilon
$$

where $y_{r t}$ is a measure of the Gross State Product (GSP) in state $r$ at time $t ; \theta_{r}$ and $\theta_{t}$ represent vectors of state and year fixed effects, respectively; $p_{r t}$ gives the ratio of the number of working immigrants to the size of the workforce in the state $(\times 100)$; and $h_{r t}$ measures the human capital of the state's workforce (which I proxy by the log mean years of education and by the fraction of workers aged 25 and 54).

The top panel of Table 1 reports the coefficients estimated by ordinary least squares. There is a positive (and significant) correlation between immigration and GSP across states and over time. An increase in the immigrant share of 1 percent is associated with a 3.2 percent increase in GSP. Note, however, that the coefficient becomes insignificant when the regression uses per-capita GSP as the dependent variable.

\footnotetext{
${ }^{3}$ Kane and Rutledge (2018) conduct a similar analysis for the $1980-2015$ period. The panel used in Table 1 consists of seven cross-sections $(1960,1970,1980,1990,2000,2010$, and 2017) and 50 states (the District of Columbia is excluded from the regressions). I also estimated the regressions using a first-difference specification. The results are qualitatively similar to those reported below.
} 
The regression model in equation (22), which is exactly analogous to the panel regression typically estimated to measure the wage impact of immigration (Borjas, 2014), suffers from potential endogeneity bias. Income-maximizing immigrants will likely settle in states that offer vibrant economic conditions, building in a positive correlation between $y_{r t}$ and $p_{r t}$. The bottom panel of Table 1 reports the coefficients estimated from IV regressions that use the generic "shift-share" instrument to control for the endogeneity (Card, 2001).

In particular, I used the 1960 census to observe the geographic settlement of immigrants who originated in a particular country. The key assumption of the shift-share instrument is that this initial geographic distribution influences the settlement of later waves of immigrants from that same country. Future immigrants will find it cheaper to settle in those parts of the country where ethnic networks facilitate the move. The shiftshare instrument uses the 1960 geographic distribution to geographically allocate the immigrants from that country observed in a subsequent cross-section $\tau$. The predicted number of immigrants living in state $r$ at time $\tau$ is then obtained by adding up across countries of origin, and this prediction is used to calculate the predicted fraction of immigrants in the workforce. Note, however, that if the economic conditions that induced the 1960 immigrants to settle in particular states persist over time, the shift-share instrument does not solve the endogeneity problem (Jaeger, Ruist, and Stuhler, 2018).

The IV estimates of the "causal" link between immigration and GDP reported in Table 1 are again positive for the level of GSP but turn negative (and insignificant) when looking at per-capita GSP. A one-point increase in the immigrant share is associated with a 1.9 percent increase in GSP, and with a 0.7 percent decrease in per-capita GDP. 
The prudent inference from the exercises reported in this section seems to be that the correlation between immigration and per-capita income is, at best, zero. The data do not provide any support for the hypothesis that the two variables are strongly and positively correlated, either historically or across regions. It seems that a finding of strong positive effects will require much more data manipulation (and many more assumptions).

\section{The Immigration Surplus}

The negative short-run impact of immigration on wages and the positive impact on the return to capital imply that immigration has distributional consequences. They also raise the possibility that the gains to firms exceed the losses to workers, and there might be an immigration surplus, a net increase in the wealth of the "native" population.

The simplest model of the immigration surplus assumes that immigrants and natives are perfect substitutes (Borjas, 1995). The workforce has $N$ native and $M$ immigrant workers, with $L=N+M$. The aggregate production function $Y=f(K, L)$ is linear homogeneous. Suppose further that natives own the capital stock and that the supplies of both natives and immigrants are perfectly inelastic.

Each factor price equals the respective value of marginal product in a competitive labor market. The rental rate of capital in the pre-immigration equilibrium is $r_{0}=f_{K}(K, N)$ and the price of labor is $w_{0}=f_{L}(K, N)$, where output price is the numeraire. Linear homogeneity implies that the entire output is distributed to the owners of capital and to workers. In the pre-immigration regime, the national income accruing to natives, $Y_{N}$, is given by $Y_{N}=r_{0} K+w_{0} N$. 
Figure 2 illustrates this initial equilibrium. The value of $Y_{N}$ is given by the area under the marginal product of labor curve $f_{L}$, or trapezoid ABN0. In the short run, the capital stock is fixed. The entry of $M$ immigrants shifts the supply curve and lowers the wage to $w_{1}$. The area in the trapezoid ACL0 gives national income in the post-immigration economy. Part of the increase in national income goes to immigrants (who earn $w_{1} M$ dollar). The area in the triangle $\mathrm{BCD}$ gives the immigration surplus, the increase in income that accrues to natives.

The immigration surplus, as a fraction of national income, approximately equals:

$$
\frac{\Delta Y_{N}}{Y}=-\frac{1}{2} s_{L} \varepsilon p^{2},
$$

where $s_{L}$ is labor's share of income $\left(s_{L}=w L / Y\right) ; \varepsilon$ is the wage elasticity $(\varepsilon=d \log w / d \log L)$; and $p$ is the immigrant share of the workforce $(p=M / L)$.

Equation (23) gives a simple formula for doing a "back-of-the-envelope" calculation (summarized in Table 2). The share of labor income has hovered around 70 percent for some time, and the fraction of immigrants in the workforce is 16.6 percent. Suppose further that the linear homogeneous production function is Cobb-Douglas. It is then easy to show that the absolute value of the wage elasticity $\varepsilon$ equals capital's share of income, or about 0.3. The immigration surplus is then 0.29 percent of GDP. In 2017, GDP was $\$ 19.5$ trillion, so that the short-run immigration surplus is about $\$ 56$ billion a year, a relatively small number in the context of a very large economy.

Figure 2 shows that immigration redistributes income from labor to capital. Native workers lose the area in the rectangle $w_{0} \mathrm{BD} w_{1}$, and this quantity plus the surplus accrues to employers. Table 2 also reports the implied dollar value of these losses and gains (see Borjas, 1995, for algebraic details). Native-born workers lose about 2.9 percent of GDP, 
while native-owned capital gains about 3.2 percent of GDP. The $\$ 19.5$ trillion GDP implies that workers lose $\$ 567$ billion while employers gain $\$ 623$ billion. The small surplus of $\$ 56$ billion masks a sizable redistribution from workers to the users of immigrant labor.

Note that the immigration surplus, which measures the dollar gains accruing to "natives," is conceptually different from the total increase in GDP. As Table 2 also shows, a supply shock that increased the workforce by almost 17 percent generated a very sizable increase in GDP, of over $\$ 2$ trillion. Almost all of this increase, however, goes to the immigrants themselves as payments for their services.

Finally, the short-run surplus derived in Figure 2 assumed that capital was fixed. The rise in the returns to capital encourages capital inflows until the rental rate is again equalized across markets. The assumption of constant returns implies that the expansion in the capital stock reestablishes the pre-immigration capital/labor ratio. In the end, immigration does not alter the price of labor or the returns to capital, and natives neither gain nor lose from immigration. In the long run, the immigration surplus must be zero.

\section{Heterogeneous Labor}

Figure 2 assumed natives and immigrants are perfect substitutes. There may exist production complementarities between the two groups that can increase the gains. Suppose there are two types of workers, low-skill $\left(L_{U}\right)$ and high-skill $\left(L_{H}\right)$. The linear homogeneous production function is now $Y=f\left(K, L_{U}, L_{H}\right)$. Suppose further the supply shock is not "balanced" across skill groups (i.e., immigrants are predominantly low-skill or highskill). The long-term adjustment in the capital stock would not lead to a new equilibrium 
with the economy simply operating at a proportionately higher scale for all inputs. ${ }^{4}$ The potential complementarities between immigrants and natives would help produce a larger immigration surplus.

Not surprisingly, capital-skill complementarity suggests that the short-run surplus might be larger if the immigrant flow was composed of high-skill workers. By assumption, natives own the capital stock and capital-skill complementarity implies that the returns to capital increase more when immigrants are high-skill. In fact, simulations of the model suggest that estimates of the short-run immigration surplus might double if the United States admitted only high-skill immigrants (Borjas, 2014, p. 158). However, the long-run capital adjustments would attenuate the importance of capital-skill complementarity and greatly reduce the gains from high-skill supply shocks.

\section{Human Capital Externalities}

The calculation of the immigration surplus with a linear homogeneous production function suggests that even a large supply shock of high-skill workers may not generate relatively large gains for the native population. Nevertheless, there is a widespread (and unshakeable) perception that some types of immigration, and particularly the immigration of high-skill workers, can be hugely beneficial. This perception relies on a crucial departure from the textbook model, the belief that high-skill immigrants generate human capital

\footnotetext{
${ }^{4}$ In the homogeneous labor case, an increase of $x$ percent in the number of workers induces an $x$ percent increase in the capital stock so that the long-run equilibrium has the economy operating at a larger scale with the same proportionate increase in capital, labor, and output. In the heterogeneous labor case with an unbalanced supply shock, the input ratios would be different in the pre- and post-shock equilibriums.
} 
externalities. The sudden presence of high-skill immigrants exposes natives to new forms of knowledge, increases their human capital, and makes them more productive.

It is easy to illustrate how externalities change the immigration surplus. If high-skill immigrants had positive spillover effects on native productivity, an influx of immigrants produces an outward shift in the labor demand curve because the value of marginal product for every native worker rises. Immigration then shifts not only the supply curve, but also shifts the demand curve to $F_{L}$ in Figure 3 . The change in income accruing to natives is then given by the sum of the triangle $\mathrm{B}^{\prime} \mathrm{C}^{\prime} \mathrm{D}$ (or the traditional immigration surplus) plus the shaded area of the trapezoid $A^{\prime} \mathrm{B}^{\prime} \mathrm{BA}$, which measures the impact of immigration on the total product of native workers. It is obvious that if the externalities are sufficiently important, high-skill immigration could be an important driver of economic growth.

Figure 3 suggests a trivial back-of-the-envelope calculation that illustrate just how important the externalities can be. Suppose a high-skill supply shock raises the marginal product of every native worker by $\varphi$ percent, so that the new demand curve $F_{L}=(1+\varphi) f_{L}$. This formulation implies that the gains produced by the externalities equal $\varphi$ percent of the original GDP. Table 2 suggests that the pre-immigration GDP, measured by trapezoid ABN0 in Figure 3, is about $\$ 17$ trillion. If the externality increases marginal product by 1 percent, the gains produced by high-skill immigration would be about $\$ 170$ billion. In short, the gains from human capital externalities can easily dwarf those measured by the traditional immigration surplus. Moreover, these large gains do not disappear in the long run, as the increased productivity of the native workforce is a permanent fixture of the labor market.

\section{The Distributional Impact of Immigration}


In the absence of human capital externalities, the canonical model of the labor market suggests that a one-time supply shock will depress the wage of competing workers in the short run, and that this negative effect is attenuated over time as the economy adjusts to the larger workforce. Despite the intuitive appeal of these insights, the literature that estimates the wage elasticity (the crucial parameter for calculating both the gains from immigration and the distributional impact) has instead produced a confusing labyrinth, with estimates that often depend on the methodological approach, the sample used, and the period examined.

Because immigrants cluster in a relatively small number of geographic areas, many studies exploit the geographic dispersion of immigrants to measure the wage effect. These studies compare native earnings in cities where the immigrant share of the workforce is large (for example, Los Angeles) with earnings in cities where there are relatively few immigrants. A negative spatial correlation would then be interpreted as showing that the supply shock reduced the wage of substitutable natives.

The regression model is typically given by:

$$
\log w_{r t}=\beta p_{r t}+\gamma X_{r t}+\varepsilon
$$

where $w_{r t}$ is the mean wage of native workers in city $r$ at time $t$, and $p_{r t}$ is the immigrant share. The vector $X$ typically includes variables that also generate wage dispersion across cities and over time and are often proxied by city and year fixed effects.

It is well known that the OLS estimate of $\beta$ does not measure the causal effect of immigration. Immigrants tend to settle in high-wage cities. The endogenous geographic distribution then generates a positive spurious correlation between immigration and native wages. As noted earlier, most studies use a shift-share instrument to address the 
problem. This instrument gives the predicted number of immigrants in a city at time $t$ based on the geographic distribution of earlier waves. The shift-share instrument, however, is valid only if the economic conditions that motivated earlier waves to settle in particular cities are uncorrelated with the conditions in those cities today.

Some studies avoid the endogeneity problem by searching for natural experiments where large numbers of immigrants are randomly "dropped off" in a particular location at a particular time, with the Mariel boatlift being the classic context. On April 20, 1980, Fidel Castro declared that Cubans wishing to move to the United States could leave freely from the port of Mariel. By September 1980, about 125,000 Cubans had accepted the invitation, and Miami's labor force had unexpectedly grown by 8 percent.

Card (1990) concluded that the average wage in Miami was barely affected by the Mariel supply shock (relative to wage trends in comparable cities). Borjas (2017), however, noted that the refugees were predominantly low-skill. Nearly two-thirds of the Marielitos did not have a high school diploma, increasing the number of high school dropouts in Miami by nearly 20 percent. It would then make sense to look for the impact of Mariel in Miami's low-skill labor market. Figure $4 a$ shows the wage trends revealed by the March Current Population Surveys (CPS) in the sample of non-Hispanic men, aged 25-59, who did not have a high school diploma. The relative wage of this group in Miami took a nosedive after 1980 , and it took a decade for the wage to recover.

Several subsequent studies have argued that other definitions of the "low-skill" workforce and that adjusting for sampling issues in the CPS yield different results. Peri and Yasenov (2015), for instance, examine the wage trends in a low-skill sample given by nonCuban workers, aged 16-61, who did not have a high school diploma. As Figure $4 b$ shows, 
the wage trends in this sample suggest that Mariel did not affect the low-skill wage. ${ }^{5}$ The question then becomes: which sample best captures conditions in Miami's "low skill" labor market? As an example of the nuances involved, the addition of workers aged 16-18 to the low-skill sample implies that high school students are classified as "high school dropouts" because they do not yet have a high school diploma and the CPS (at the time) did not provide information on whether a person was enrolled in school. The very large number of high school students overwhelms the data and potentially contaminates the wage trend. ${ }^{6}$

Spatial correlations might also be problematic because natives may respond to supply shocks migration by moving to other labor markets. If the entry of immigrants into a particular city lowers the wage, natives might move to places unaffected by immigration that now offer relatively higher wages, diffusing the impact of immigration over the national economy. Beginning with Borjas (2003), many studies have moved away from geographic comparisons and instead examined wage trends for specific skill groups in the national labor market. The "skill-cell approach" tries to determine if the wage of specific skill groups is related to the number of immigrants that entered each of those groups.

Figure 5 illustrates a key empirical implication of this approach. Define a skill group as the set of workers with a particular combination of educational attainment and labor market experience (for example, high school dropouts with 6-10 years of experience, or

\footnotetext{
5 This is the sample used in the original draft of Peri and Yasenov (2015). Recent work by Clemens and Hunt (2019) notes an additional problem with the March CPS sample: the fraction of the low-skill workforce that is black jumped dramatically in 1979, potentially contaminating the wage trend. Borjas (2019), however, documents that much of the wage decline documented in Figure $4 a$ actually occurred during a time when the fraction of black workers in the CPS sample was relatively constant.

6 The reconciliation of the Mariel evidence will likely require data that examines aspects of the Miami labor market not measured by the CPS. Anastasopoulos et al (2018) examine trends in the number of job vacancies (as measured by the Conference Board Help-Wanted Index) and document a sizable post-Mariel decline in the relative number of help-wanted classifieds in the Miami Herald.
} 
college graduates with 20-24 years of experience). Each point in the scatter diagram relates the wage growth experienced by a particular skill group of natives over a particular decade to the change in the percent of the group that is foreign born (using decadal Census data from 1960 through 2010). There is an obvious negative correlation between the two variables, and the regression line suggests that a 10 percent increase in the size of the skill group reduces the wage of that group by 3 to 4 percent.

As this brief overview of a huge literature suggests, there are methodological and sampling choices that often lead to very different conclusions. A recent National Academy of Sciences (NAS) report on the economic impact of immigration (Blau and Mackie, 2016) summarized the value of the wage elasticity estimated in the main studies. Table 3 shows that the point estimates are all over the map, and can be positive, zero, or negative.

The skill-cell approach can be expanded to address a limitation of the generic regression model in equation (24). A supply shock in a particular skill group affects the wage of workers in that skill group and the wage of other skill groups as well. Given the vast number of potential skill groups in the workforce, the cross-effects can only be estimated by specifying a structural model of the production technology that limits the allowable interactions. Borjas (2003) introduced the nested CES framework:

$$
\begin{aligned}
Q_{t} & =\left[\lambda_{K t} K_{t}^{\delta}+\lambda L_{t}^{\delta}\right]^{\frac{1}{\delta}} \\
L_{t} & =\left[\sum_{s} \theta_{s t} L_{s t}^{\beta}\right]^{\frac{1}{\beta}}, \\
L_{s t} & =\left[\sum_{x} \alpha_{s x t} L_{s x t}^{\eta}\right]^{\frac{1}{\eta}},
\end{aligned}
$$


where $Q_{t}$ is output, $K_{t}$ is capital, $L_{t}$ denotes the number of efficiency units in the aggregate labor market; $\delta=1-1 / \sigma_{K L}$, with $\sigma_{K L}$ being the elasticity of substitution between capital and labor; $L_{s t}$ gives the effective supply of workers with education $s$ at time $t ; \beta=1-1 / \sigma_{S}$, with $\sigma_{S}$ being the elasticity of substitution across these education aggregates; $L_{s x t}$ gives the number of workers in education group $s$ and experience group $x$ at time $t ; \eta=1-1 / \sigma_{X}$, with $\sigma_{X}$ being the elasticity of substitution across experience classes.

The structural approach shows that the elasticities of substitution among different types of workers are the "fundamentals" that determine the wage impact of immigration. The (log-linear) marginal productivity conditions implied by the nested CES allow for easy estimation of these elasticities using data on wages and employment for the skill cells. Table 4, also drawn from the NAS report, uses the estimated elasticities to simulate the wage impact of the immigrants who entered between 1990 and 2010 (who are treated as a one-time shock). Even after accounting for all potential cross-effects, this supply shock reduced the wage of the least skilled workers by 6.3 percent in the short run and by 3.1 percent in the long run.

Subsequent extensions of the framework in equations (25)-(27) emphasize the importance of two additional elasticities of substitution that may change the implications of the numerical simulation. Ottaviano and Peri (2012) relaxed the assumption in equation (27) that immigrants and natives who have the same educational attainment and the same labor market experience are perfect substitutes. The potential complementarity between observationally equivalent immigrants and natives would attenuate any negative wage 
effect. Card (2009) argued that high school dropouts and high school graduates are perfect substitutes, changing the definition of the low-skill workforce.

The various panels of Table 4 show how the alternative assumptions change the simulated wage impact. The Ottaviano-Peri (2012) estimate of an elasticity of substitution of 20 between observationally equivalent immigrants and natives is too large to matter much in the simulation. The short-run impact on the wage of high school dropouts is -4.9 percent, while the long-run impact is -1.7 percent. But the assumption that high school dropouts and high school graduates are perfect substitutes makes a difference. By adding the tens of millions of natives who are high school graduates into the low-skill labor market, the impact of the entry of millions of low-skill immigrants (who often do not have a high school diploma) is diluted because the baseline workforce grows even more. It is this "numerical trick" that produces a simulation suggesting that immigration has no adverse impact on the wage of low-skill workers.

\section{Human Capital Externalities}

Human capital externalities can attenuate the adverse impact of immigration on competing workers and generate very large economic gains at the same time. A number of recent studies examine specific historical events involving high-skill supply shocks to determine if there were resulting externalities.

The work of Waldinger $(2010,2012)$ exemplifies the methodological approach. Immediately after seizing power in 1933, the National Socialist Party enacted the Law for the Restoration of the Professional Civil Service, which mandated the dismissal of all Jewish professors from German universities. Almost 20 percent of German mathematics 
professors were dismissed, including some of the most famous mathematicians of the era (such as John von Neumann, Richard Courant, and Richard von Mises).

The Jewish mathematicians had not been randomly employed across German universities, so some departments barely noticed the dismissals while other departments lost over half their faculty. If those exceptional mathematicians produced beneficial externalities for their students or colleagues, the dismissals would have had a detectable impact on the eventual productivity of the persons "left behind." Waldinger (2010) shows that the students left behind in the departments that suffered the heaviest losses experienced a relative decline in their productivity, suggesting that human capital externalities do matter. Waldinger (2012), however, documents that the publication rate of the colleagues left behind was not affected by the dismissals. The different results in the two Waldinger studies suggest that human capital externalities are not magically produced even when the supply shock involves exceptional workers. The outcome seems to depend on the nature of the relationship between the immigrants and the affected workers.

Borjas and Doran (2012) conduct a similar examination of another high-skill supply shock. For decades prior to 1992, there had been little intellectual contact between Soviet and Western mathematicians. As a result, the two groups specialized in very different fields. The two most popular Soviet fields were partial differential equations and ordinary differential equations. The two most popular American fields were statistics and operations research. After the collapse of the Soviet Union in 1992, several hundred Soviet mathematicians left the country and settled in the United States. 
Borjas and Doran (2012) tracked the publication record of every American mathematician before and after the arrival of the Soviet émigrés to measure the impact of the supply shock on the mathematicians who had the most Soviet-like research agenda. There are two possible effects. The first is implied by the law of diminishing returns. An increase in the number of mathematicians deriving theorems in, say, partial differential equations makes the comparable American mathematicians less productive. The second is implied by human capital externalities. Exposing American mathematicians to new theorems and techniques could increase the productivity of the mathematicians working in those fields. It turns out that there was a precipitous decline in the publication rate of the group whose research agenda overlapped most with the Soviets.

Finally, several studies examine the impact of the high-tech workers admitted in the $\mathrm{H}-1 \mathrm{~B}$ visa program. The number of $\mathrm{H}-1 \mathrm{~B}$ visas is capped and this cap has fluctuated over time. The conclusion that the H-1B program produces externalities often comes from studies that estimate spatial correlations. Because H-1B visa-holders cluster in a small number of locations (such as San Francisco), an exogenous increase in the cap would be expected to have a large impact in "H-1B dependent" cities. Kerr and Lincoln (2010) showed that an increase in the cap led to more patents originating in those cities. The increased patenting, however, came mainly from persons with Indian or Chinese surnames, suggesting that those new patents originated with the immigrants themselves, rather than from a spillover effect on native workers.

Some of the subsequent studies that estimate spatial correlations report large beneficial effects. Peri, Shih, and Farber (2015) relate the H-1B induced increase in the number of STEM workers to the wage of college graduates in the city and find a very strong 
positive effect. The magnitude, however, seems implausible; a 1 percent increase in the size of the STEM workforce raises the wage of college graduates by 8 percent (or a wage elasticity of +8.0 ). Most likely, the endogeneity plaguing spatial correlations and the problems with the shift-share instrument lead the data to regurgitate the obvious fact that high-skill immigrants end up in places where the high-skill labor market is doing quite well.

Doran, Gelber, and Isen (2016) avoid the endogeneity bias by examining a natural experiment created by a peculiarity of the H-1B program. Firms can apply for the visas on a first-come, first-served basis until the visas run out. On some random day during a year, the visas run out and on that day more firms typically apply for visas than there are visas available. The Department of Homeland Security then runs a lottery to determine which firms get the visas. It turns out that the firms that won the lottery did not patent more and that native employment in those firms fell.

In short, the evidence supporting the conjecture that high-skill immigration generates sizable human capital externalities is mixed. There are some historical events

that produced such externalities, but there are also other events where the externalities are absent.

\section{Immigrant Skills}

As the augmented Solow model suggests, the impact of immigrants on economic growth depends on the human capital stock they bring into the country, and on how that stock changes as assimilation takes place (Chiswick, 1978; Borjas, 1985).

The 2016 NAS report (Blau and Mackie, 2016) used the census cross-sections between 1970 and 2010 to track the age-adjusted wage of specific immigrant waves over 
the past few decades. Figure $6 a$ illustrates the trends in the relative wage. The figure reveals two interesting and well-known findings. The first is the presence of sizable cohort differences in entry wages, with the more recent cohorts having lower earnings potential than earlier cohorts through the year 2000. In 1970, the most recent immigrant wave earned 23.5 percent less than comparable natives at the time of entry. By 1990, the entry wage disadvantage had grown to 33.1 percent, before contracting to 27.3 percent in 2000 .

Figure $6 a$ also hints at a slowdown in the rate of "economic assimilation." The immigrant cohorts that arrived prior to the early 1980s experienced faster relative wage growth than the more recent arrivals. Consider, for example, the cohort that arrived in the late 1960s. The relative wage of this group improved from a disadvantage of 23.5 percent in 1970 to 2.0 percent by 2000 - a growth of about 20 percentage points over two decades. In contrast, the relative wage of the cohort that entered the country in the late 1980s only improved from an entry disadvantage of 33.1 percent to 25.2 percent by 2010 .

The assimilation slowdown is also evident in data that is far less sensitive to the impact of transitory economic conditions on the relative wage of immigrants. Figure $6 b$ shows the comparable trends in the fraction of immigrants who speak English very well (or only speak English). Note that 30.9 percent of the immigrants who arrived between 1975 and 1980 were English proficient at the time of arrival, and this fraction increased to 46.2 percent by 2000 . In contrast, the proficiency rate of the cohort that entered the country in the late 1980 s increased by only 7 percentage points during the first 20 years. The evidence revealed in Figure 6, therefore, suggest that there is no inevitable assimilation process that will mechanically increase per-capita income as the immigrant population acquires skills that attenuate the initial productivity disadvantage. 
It is insightful to compare the modern evidence with the historical record. Although it is widely believed that the human capital stock of the immigrants who arrived at the beginning of the $20^{\text {th }}$ century increased dramatically during their lifetime, recent research suggests that the widespread consensus may be wrong. The public release of the census manuscripts compiled at the time allows modern historians to track specific persons from census to census. This tracking lets us inspect the career path of specific natives and immigrants. The exercise turns the widespread perception of rapid improvement on its head. As Abramitzky, Boustan, and Eriksson (2014, pp. 269-270) conclude: "The notion that European immigrants converged with natives after spending 10 to 15 years in the US is...exaggerated, as we find that initial immigrant-native occupational gaps persisted over time." In short, the historical experience provides surprisingly little evidence of any relative economic improvement for the Ellis Island immigrants during their lifetime.

Finally, the available evidence suggests a positive correlation between the skills that immigrants bring into the United States and the rate of subsequent growth in earnings. Figure 7 illustrates the link the wage of growth experienced by a national origin group in the first 10 years in the United States and the average education of the group at the time of arrival. It is evident that more skilled groups experience faster assimilation. The evidence, therefore, supports the conjecture of complementarity in the production of human capital: those immigrants who invested more in human capital prior to migration are likely to invest more in human capital after migration. Put differently, the relative economic contribution of high-skill immigrants to aggregate output increases over time.

\section{The Fiscal Impact}


Immigration generates a short-run economic gain through the immigration surplus and may generate a long-run increase if immigrants are sufficiently skilled or there are human capital externalities. The economic gains that accrue through the labor market, however, need to be contrasted with the fiscal impact of immigration. The fiscal impact can either be positive or negative, depending on how much immigrants contribute to the funding of government programs and how much it costs to provide services to them.

The question of whether immigrants use government programs more or less often than natives is controversial and the answer is highly disputed. In fact, it is enlightening to illustrate how the same data can be manipulated in different ways to reach very different conclusions about the relative use of welfare programs by the immigrant population.

Since 1994, the Current Population Surveys (CPS) provide information on participation in various assistance programs for both immigrants and natives, making it possible to document the difference in welfare participation rates. For expositional convenience, suppose that being "on welfare" means receiving benefits from Medicaid, food stamps, or cash benefits. We can then use the CPS to determine if the fraction of immigrants on welfare is higher, lower, or the same as the fraction of natives.

The two panels of Figure 8 show the trends between 1994 and 2018. Note, however, that the two panels yield very different results. In Figure $7 a$, the fraction of immigrants on welfare is far higher than the fraction of natives, while in Figure $7 b$, the participation rate is essentially the same for the two groups.

Both panels of the figure use the same data but manipulate it in different ways. In particular, the two panels use a different unit of analysis in the calculations. Figure $7 a$ uses the household as the unit of analysis, which is the way in which welfare use is most often 
analyzed. An immigrant household is one where the head of the household is foreign-born, and a native household is one where the head is native-born. It is evident that households headed by an immigrant have high rates of welfare use (defined as anyone in the household receiving one of the three programs under analysis), and that the gap between immigrant and native households increased over time. By 2018, 35.1 percent of immigrant households were on welfare as compared to 22.6 percent of native households. In contrast, Figure $7 \mathrm{~b}$ uses the person as the unit of analysis. In 2018, 24.5 percent of foreign-born persons and 23.1 percent of the native-born received assistance from one of the three programs.

The reason for the difference between the two panels is easy to grasp by considering a trivial example. A young, single immigrant woman arrives in the country. After a few years, she becomes a single mother, has three children, and qualifies for Medicaid. In Figure $8 a$, the four-person grouping would be classified as an immigrant household on welfare. In Figure $8 b$, the tally would record one immigrant person on welfare and three native persons on welfare. And therein lies the numerical trick: Because the children were born in the United States, they enter on the native side of the ledger.

The 2016 NAS report contains a detailed analysis of the fiscal impact that goes far beyond the calculation of welfare participation rates (Blau and Mackie, 2016, Chapters 8 and 9). The NAS report adds up both the taxes paid and the cost of the services received for immigrants and their descendants, so as to come up with a "bottom-line" number that summarizes the long-run fiscal impact.

This long-run perspective accounts for the fact that many current expenditures, such as funding schooling for immigrant children or health care, generate future returns through higher earnings when the children enter the labor market. The exercise also 
incorporates the possibility that immigrants might help fiscally because the native population is aging, and funds will be needed to fund current liabilities in Social Security and Medicare. The NAS used a 75-year period to calculate the long-run fiscal impact.

The NAS exercise shows that the bottom line of the long-run calculation for the average immigrant depends entirely on the assumptions made. It is easy to generate either a very positive long-run fiscal impact or a very negative one by making different assumptions. Two distinct assumptions drive the conclusion. First, the calculation needs to allocate expenditures in public goods between immigrants and natives. Although it makes sense to assume that the cost of public goods, such as police protection or national defense, is unchanged if the country admits one more immigrant (so that the marginal cost is zero), it makes less sense to assume that the cost of public goods is unchanged if the country admits over 40 million immigrants. Similarly, any long-run scenario must make assumptions about the future path of taxes and government expenditures, and different assumptions lead to different conclusions.

Table 5 summarizes the results from four scenarios presented in the NAS report. The long-run fiscal impact of the average immigrant (measured as the present value of the difference between taxes and expenditures) is positive only if immigrants do not affect the cost of public goods and we also assume that future tax rates and benefit payments follow the projections made by the Congressional Budget Office (CBO). The positive long-term impact of an immigrant (a net present value of $+\$ 58,000$ ) becomes a loss (potentially as large as $-\$ 119,000)$ if one gets rid of either of those assumptions.

Note, however, that the fiscal impact of high-skill immigration is always positive, while the fiscal impact of low-skill immigration is always negative. Although it is impossible 
to know which scenario (if any) best approximates the future, high-skill immigration is always a better "deal" from a fiscal perspective. The long-run fiscal benefit from an immigrant with a graduate degree is between $\$ 236,000$ to $\$ 547,000$, while the long-run fiscal burden imposed by a high school dropout is between $-\$ 196,000$ to $-\$ 301,000$.

These estimates imply that a change in immigration policy that only permits the entry of high-skill workers can be an important contributor to economic growth even in the absence of human capital externalities. Consider the scenario that generates the smallest fiscal gain for the average immigrant (i.e., the scenario that assumes average cost pricing for public goods and disregards the $\mathrm{CBO}$ projections). The average immigrant produces a long-term loss of $-\$ 119,000$. Suppose, however, that every immigrant had been a college graduate. The net present value in this scenario jumps from a burden of $-\$ 119,000$ to a gain of $+\$ 39,000$, or a net gain of $+\$ 158,000$. Assuming a 3 percent rate of discount, the annualized gain is $\$ 4,740$. There were 44.5 million immigrants in 2017. If all these immigrants had been college graduates, the country would have been $\$ 211$ billion richer. The projected gain is even larger in the scenario that assumes marginal cost pricing and uses the CBO projections. The increase in the country's wealth if all immigrants had been college graduates would be $\$ 311$ billion. In short, high-skill immigration can be an important determinant of economic growth simply because of its fiscal consequences. ${ }^{7}$

\section{Implications}

${ }^{7}$ This is a partial equilibrium exercise designed to give a sense of the magnitudes involved. The very large increase in the number of college graduates would have major labor market consequences, including a substantial drop in the relative wage of (and taxes paid by) high-skill workers. 
The United States offers exceptional opportunities to anyone lucky enough to live within its borders. As a result, many more people want to immigrate than the country is willing to admit. Consider, for example, the "diversity lottery" held annually since 1995. Each year, some visas are made available to persons originating in "countries with low rates of immigration to the United States." Persons living in the eligible countries can apply for a random chance at winning one of the coveted green cards. The 2018 lottery drew 23.1 million qualified applications for the 50,000 available visas.

The huge excess demand for entry visas implies that immigration policy often specifies a set of rationing rules to pick and choose from the many applicants. These rules may stress family ties (as is currently done for the bulk of legal immigrants), or national origin (as used to be done), or socioeconomic characteristics (as is done in other countries). Which types of immigrants should the country admit?

The case that can be made for preferring one type of immigrant over another ultimately depends on what one assumes about the country's policy objectives. Specifically, what should the United States seek to accomplish from immigration? Different policy goals lead to different choices about the composition of the immigrant flow. If immigration policy strived to relieve the tax burden on native-born taxpayers, it would be fiscally irresponsible to admit millions of low-skill immigrants who have a high propensity for participating in assistance programs. But if the goal were to help the millions of persons now living in poverty-stricken regions of the world, the increased cost of low-skill immigration is the price that Americans are willing to pay for their generosity.

Assume that the goal of immigration policy is to achieve a high rate of economic growth. A very strong case can be made that there would be faster economic growth, 
particularly as defined by the trend in per-capita income, if the United States adopted an immigration policy that limited entry to high-skill workers.

The argument in favor of this policy contains two distinct parts. Consider first the role of the fiscal impact of immigration. There is no doubt that high-skill immigrants earn more, pay higher taxes, and require fewer services. Put simply, high-skill immigration increases the after-tax income of natives, while the tax burden imposed by the immigration of low-skill workers reduces the net wealth of native taxpayers. And the National Academy estimates suggest that the fiscal benefits generated by high-skill immigration can be quite large.

The second part of the case for high-skill immigration relies on how immigrants alter the productivity of the native workforce and of native-owned firms. In the short-run, the economic pie expands through the immigration surplus. Many studies suggest that there is more complementarity between high-skill labor and capital than between unskilled labor and capital. Capital-skill complementarity, therefore, suggests that the immigration surplus would be larger if the immigrant flow were composed of skilled workers.

These short-run gains, however, would be dissipated as the economy adjusts to the larger workforce. In the long-term, the immigrant contribution to economic growth would depend on the possibility that immigrants introduce human capital externalities, which permanently increase the productivity of natives. High-skill immigrants are also more likely to bring in knowledge, skills, and abilities that natives lack, and natives may be able to somehow pick up this know-how. Although the evidence on the magnitude of these externalities is mixed, the potential for the externalities to even exist is larger when the immigrant influx is composed of exceptional workers. 
In short, there is little doubt that the immigrant contribution to economic growth would be far more important if the immigrant inflow was composed of high-skill workers. If a receiving country wished to pursue an immigration policy that maximized long-term growth, therefore, there is little uncertainty about the path that country should follow. It is far from clear, however, that immigration policy should be set solely on the basis of economic considerations. 


\section{References}

Abramitzky, Ran, Leah Platt Boustan, and Katherine Eriksson. 2014. "A nation of immigrants: Assimilation and economic outcomes in the age of mass migration," Journal of Political Economy 122: 467-506.

Anastasapoulos, Jason, George J. Borjas, Gavin G. Cook, and Michael Lachanski. 2018. "Job Vacancies and Immigration: Evidence from Pre- and Post-Mariel Data," NBER Working Paper No. 24580.

Barro, Robert J. and Xavier Sala-i-Martin. 1999. Economic Growth. Cambridge, MA: The MIT Press.

Borjas, George J. 1985. "Assimilation, changes in cohort quality, and the earnings of immigrants,” Journal of Labor Economics 3: 463-489.

Borjas, George J. 1995. “The economic benefits from immigration,” Journal of Economic Perspectives 9: 3-22.

Borjas, George J. 2003. "The labor demand curve is downward sloping: Reexamining the impact of immigration on the labor market," Quarterly Journal of Economics 118: 13351374.

Borjas, George J. 2014. Immigration Economics. Cambridge, MA: Harvard University Press.

Borjas, George J. 2016. We Wanted Workers: Unraveling the Immigration Narrative. New York, NY: Norton.

Borjas, George J. 2017. “The Wage Impact of the Marielitos: A Reappraisal," Industrial and Labor Relations Review 70: 1077-1110.

Borjas, George J. 2019. “The Wage Impact of the Marielitos: The Role of Race,” Industrial and Labor Relations Review, in press.

Borjas, George J., and Kirk B. Doran. 2012. "The collapse of the Soviet Union and the productivity of American mathematicians," Quarterly Journal of Economics 127: 1143-1203.

Boubtane, Ekrame, Jean-Christophe Dumont, and Christophe Rault. 2016. "Immigration and Economic Growth in the OECD Countries 1986-2006," Oxford Economic Papers: 340-360.

Card, David. 1990. "The impact of the Mariel boatlift on the Miami labor market," Industrial and Labor Relations Review 43: 245-257.

Card, David. 2001. "Immigrant inflows, native outflows, and the local labor market impacts of higher immigration," Journal of Labor Economics 19: 22-64. 
Card, David. 2009. Immigration and inequality. American Economic Review 99: 1-21.

Chiswick, Barry R. 1978. "The effect of Americanization on the earnings of foreignborn men," Journal of Political Economy 86: 897-921.

Clemens, Michael A., and Jennifer Hunt. 2019. "The Labor Market Effects of Refugee Waves: Reconciling Conflicting Results," Industrial and Labor Relations Review, in press.

Dolado, Juan, Alessandra Goria, and Andrea Ichino, 1994. "Immigration, Human Capital and Growth in the Host Country: Evidence from Pooled Country Data," Journal of Population Economics 7: 193-215.

Doran, Kirk, Alexander Gelber, and Adam Isen. 2015. "The Effects of High-Skilled Immigration Policy on Firms: Evidence from H-1B Visa Lotteries," NBER Working Paper No. 20668.

Jaeger, David A., Joakim Ruist, and Jan Stuhler. 2018. "Shift-Share Instruments and the Impact of Immigration," NBER Working Paper No. 24285.

Kane, Tim and Zach Rutledge. 2018. "Immigration and Economic Performance Across Fifty U.S. States from 1980-2015," Hoover Institution Working Paper No. 18112.

Kerr, William R., and William F. Lincoln. 2010. "The supply side of innovation: H-1B visa reforms and U.S. ethnic invention," Journal of Labor Economics 28: 473-508.

Mankiw, N. Gregory, David Romer, and David N. Weil. 1992. "A Contribution to the Empirics of Economic Growth," Quarterly Journal of Economics 107: 407-437.

Ottaviano, Gianmarco I. P., and Giovanni Peri. 2012. "Rethinking the effect of immigration on wages," Journal of the European Economic Association 10: 152-197.

Peri, Giovanni. 2012. "The Effect of Immigration on Productivity: Evidence From U.S. States." Review of Economics and Statistics 94: 348-358.

Peri, Giovanni, Kevin Shi, and Chad Sparber. 2015. "STEM Workers, H-1B Visas, and Productivity in US Cities," Journal of Labor Economics 33: S225-S255.

Peri, Giovanni and Yasenov, Vasil. 2015. "The Labor Market Effects of a Refugee Wave: Synthetic Control Method Meets the Mariel Boatlift," NBER Working Paper No. 21801.

Waldinger, Fabian. 2010. "Quality matters: The expulsion of professors and the consequences for Ph.D. student outcomes in Nazi Germany," Journal of Political Economy 118: 787-831. 
Waldinger, Fabian. 2012. "Peer effects in science: Evidence from the dismissal of scientists in Nazi Germany," Review of Economic Studies 79: 838-861. 
Figure 1. Immigration and economic growth in decadal data, 1850-2017

A. GDP

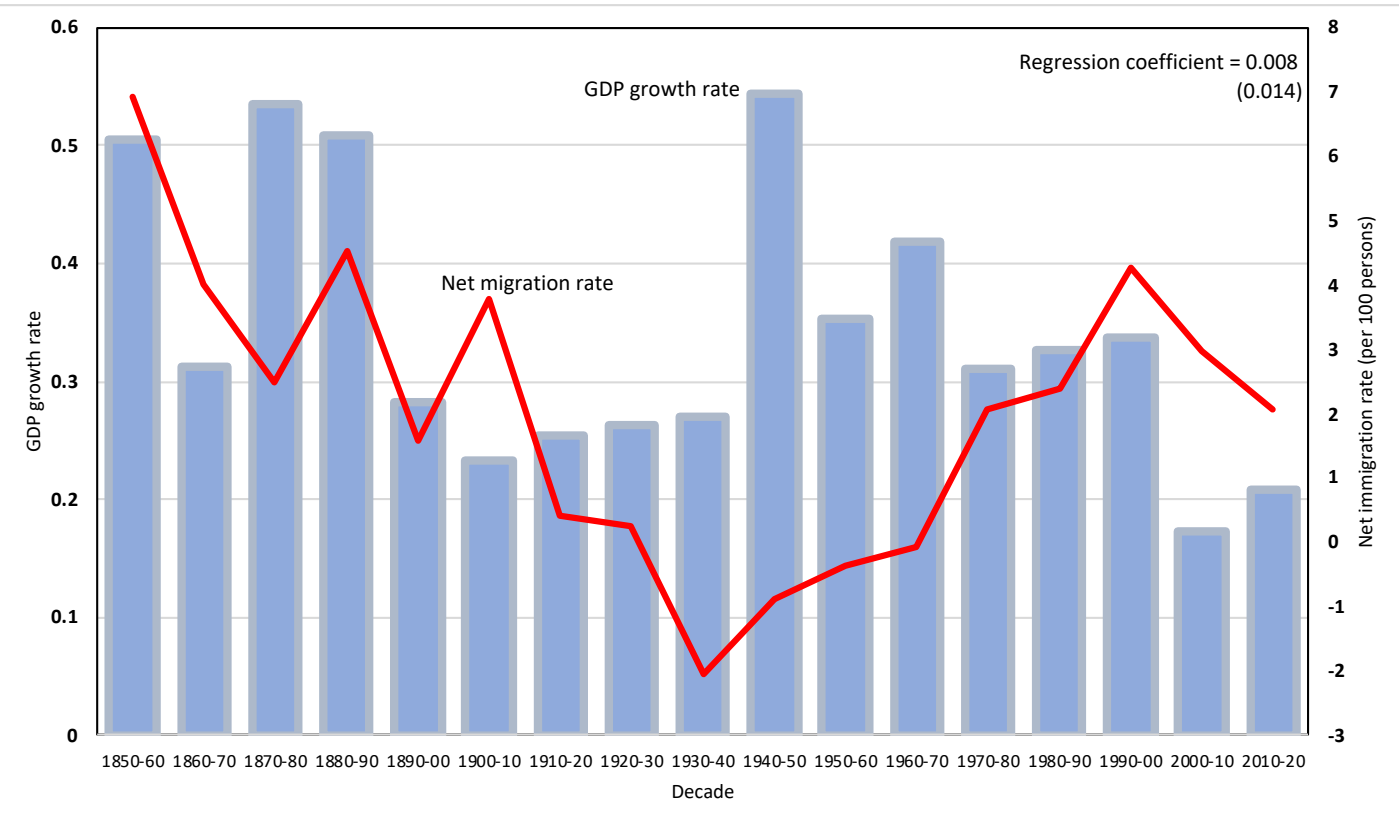

B. Per-capita GDP

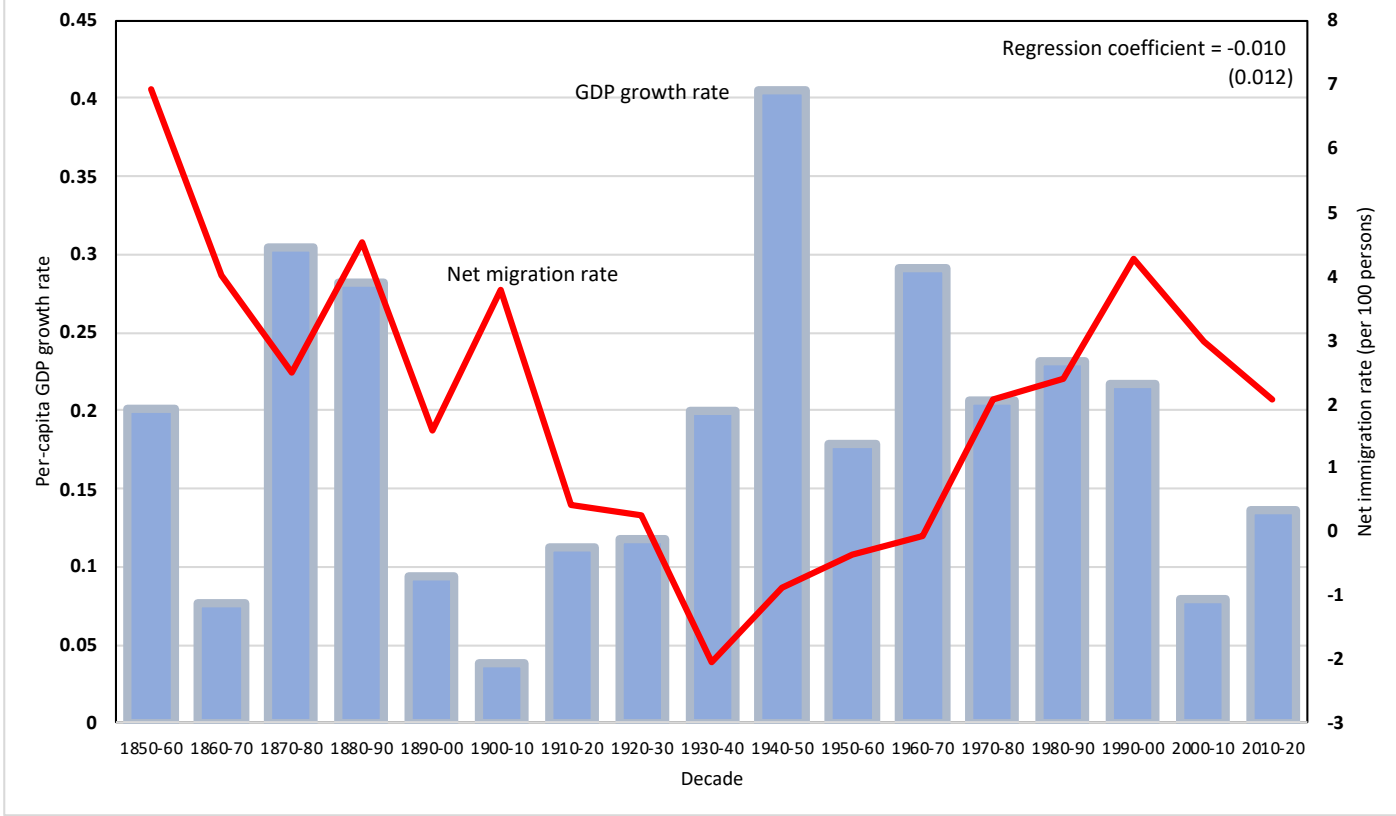

Notes: The historical GDP series was obtained from MeasuringWorth.com and the net migration data was drawn from the decennial censuses. The data for 2010-2020 are extrapolations from the changes observed between 2010 and 2017. The reported regression coefficient is the slope from an OLS regression of the decadal GDP growth rate on the net migration rate (with standard errors in parentheses). 
FIGURE 2. The immigration surplus

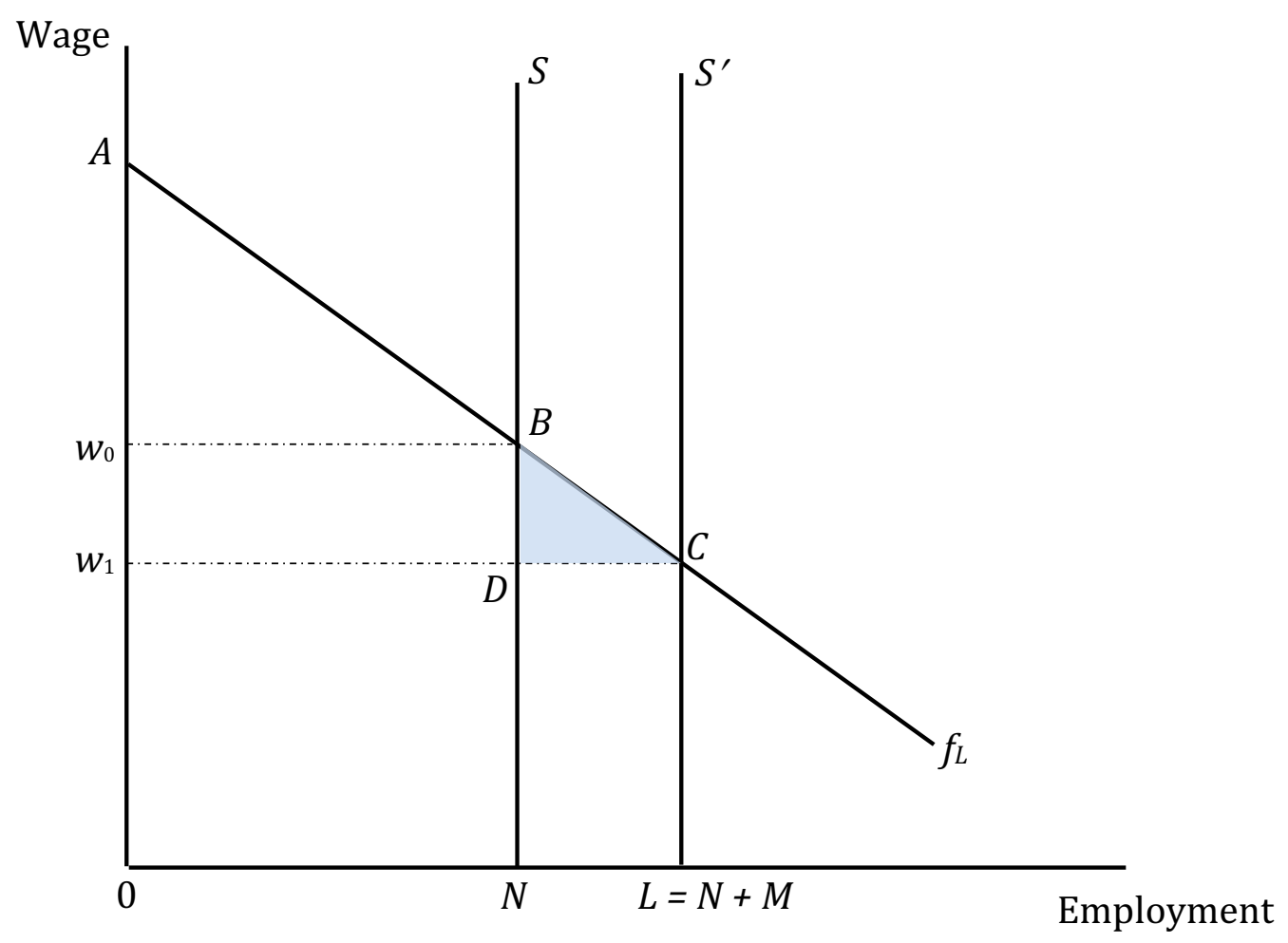


Figure 3. The immigration surplus and human capital externalities

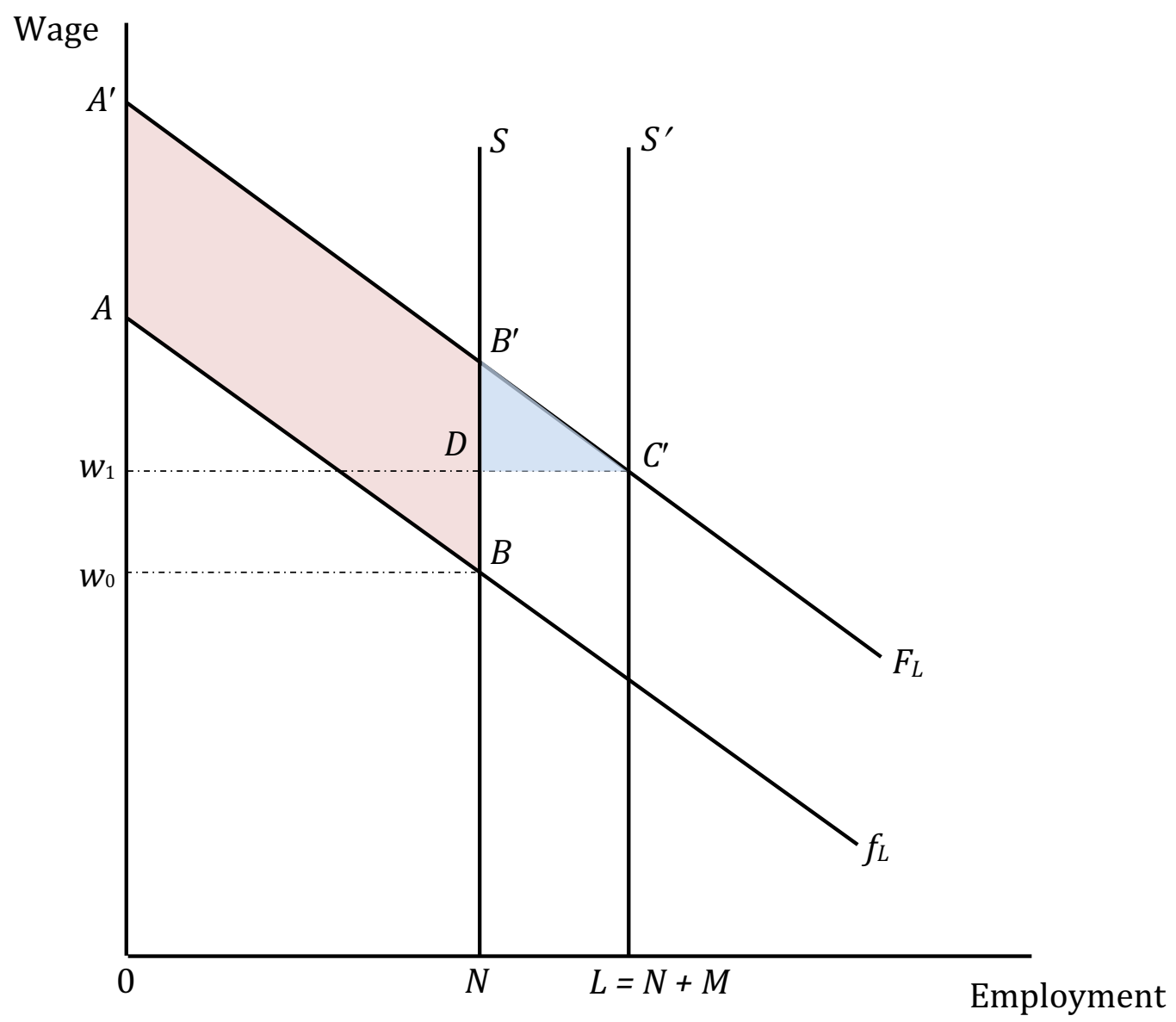


Figure 4. Mariel and the wage of high school dropouts

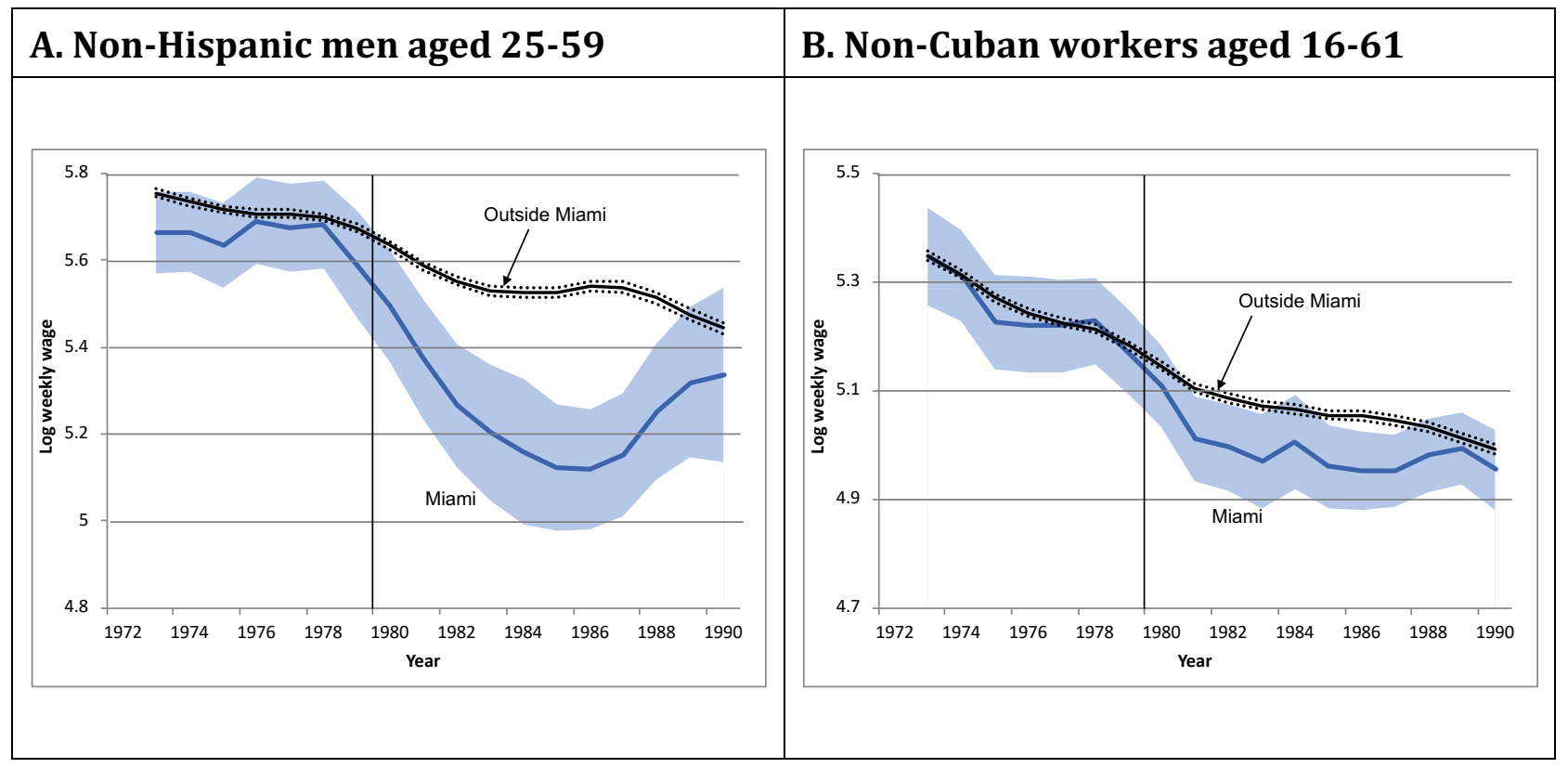

Notes: Adapted from Borjas (2017). The wage data represent a 3-year moving average and the shaded area is the 95 percent confidence interval. 
Figure 5. Scatter relating wages and immigrant share across skill groups and over time, 1960-2010

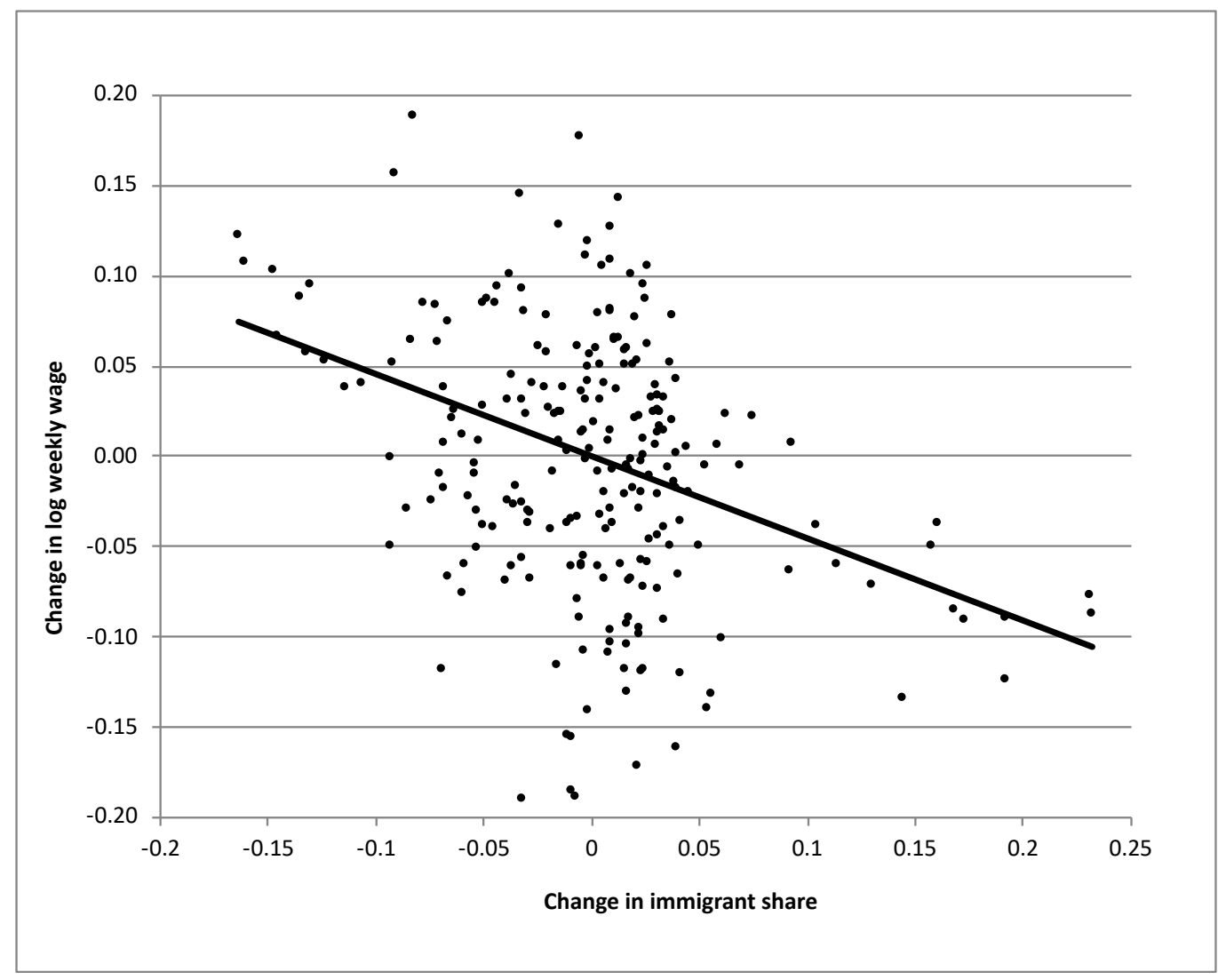

Source: Borjas (2014), p. 95. Each point in the scatter diagram gives the decadal wage change and the decadal change in the immigrant share for native working men with a particular level of education and labor market experience. 
Figure 6. Economic assimilation of immigrants, 1970-2010

\section{A. Relative wage profiles}

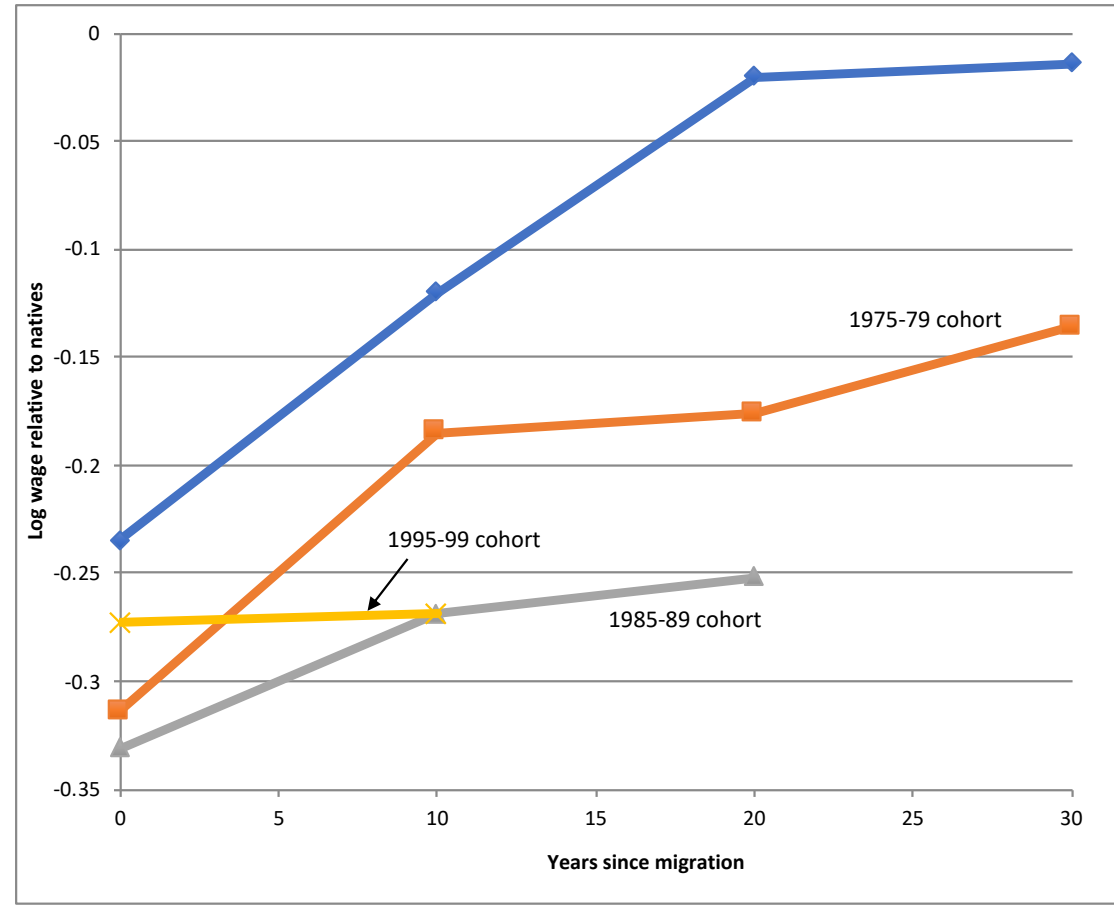

\section{B. English proficiency profiles}

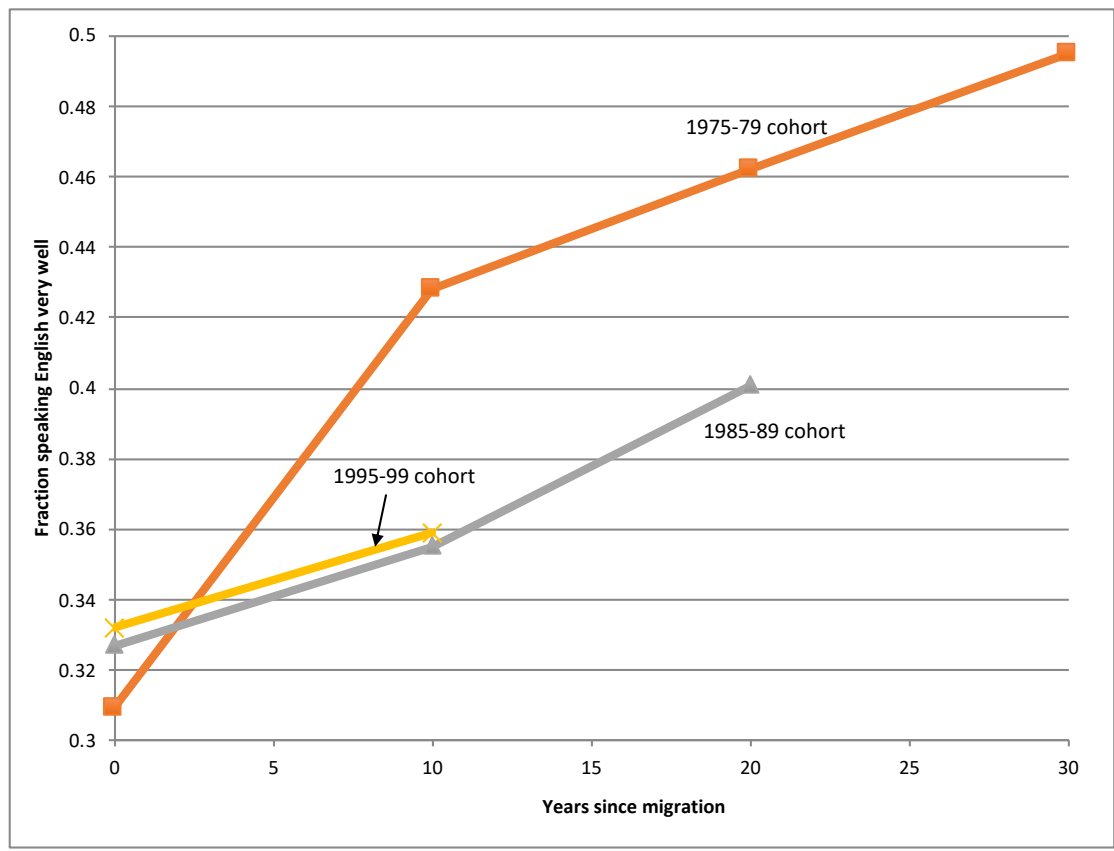

Notes: Blau and Mackie (2016), Table 3-12, p. 110, and Figure 3-16, p. 115. 
Figure 7. Economic assimilation and education

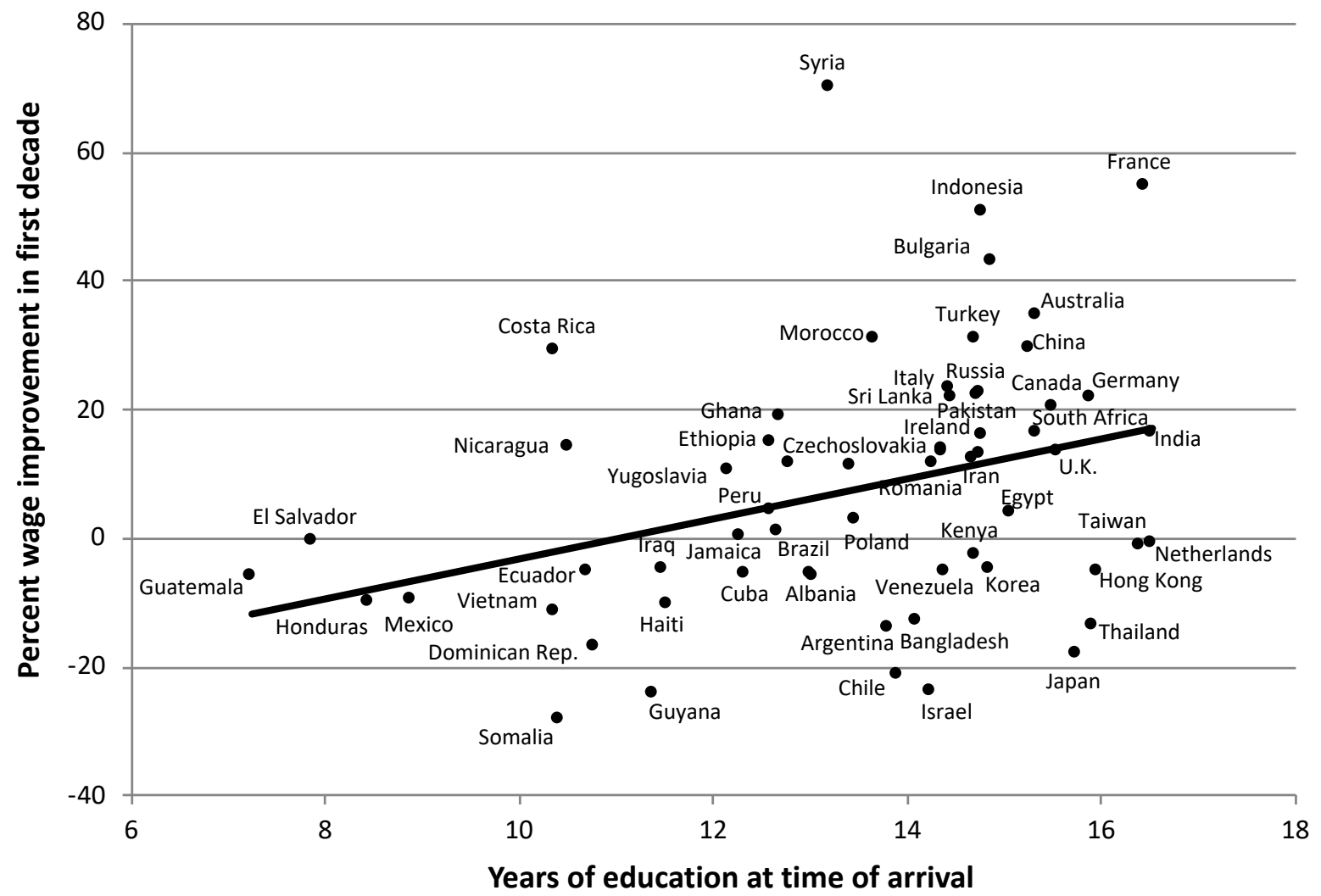

Source: Borjas (2016), p. 101. 
Figure 8. Trends in welfare participation rates, 1994-2018

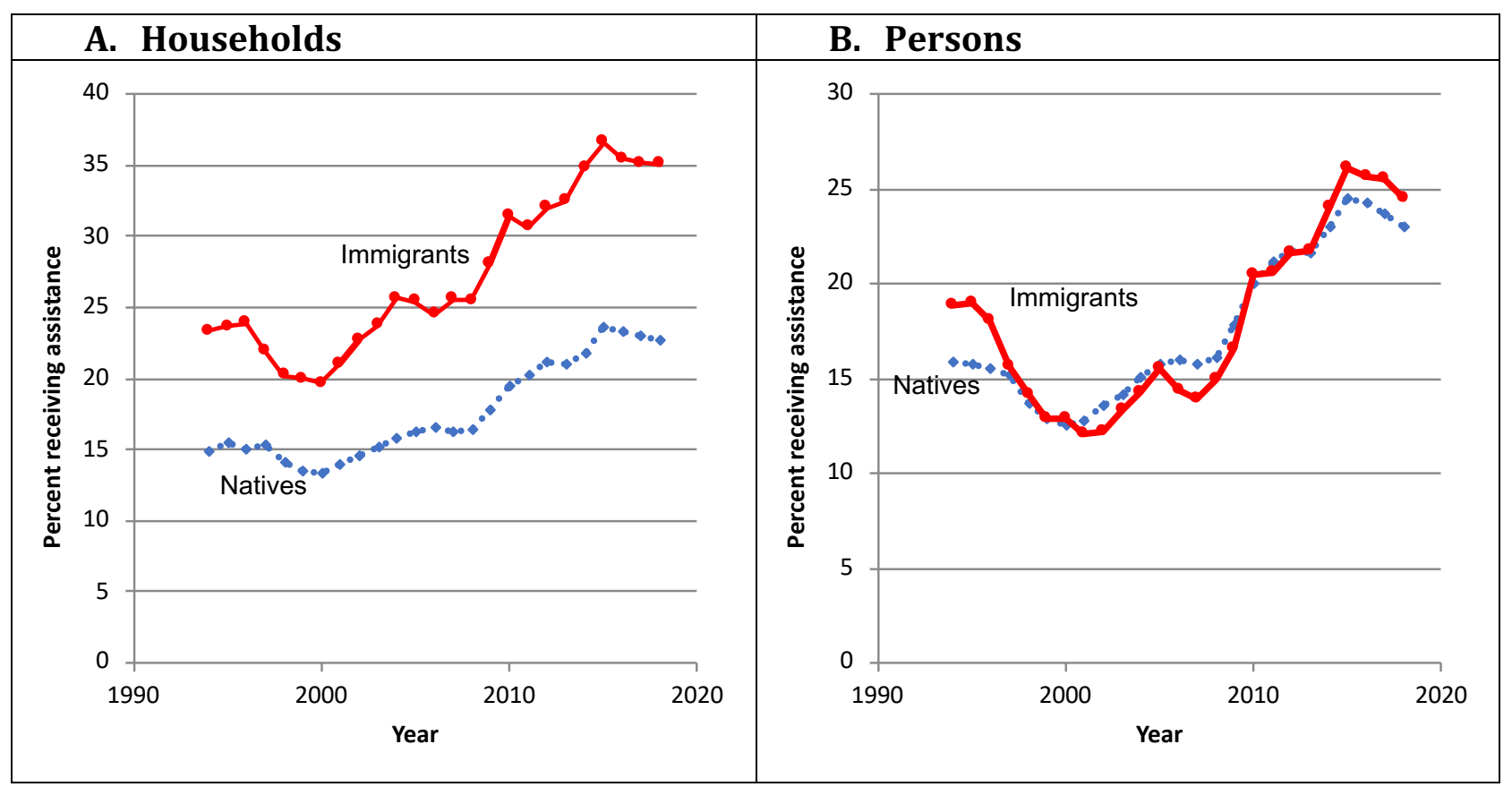

Source: Author's calculations from the Current Population Surveys, Annual Social and Economic Supplement. Welfare participation is defined in terms of use of cash benefits, food stamps, or Medicaid. 
Table 1. Immigration and GSP across states, 1960-2017

\section{Characteristics of workforce}

A. OLS

Immigrant share

Log years of schooling

Percent prime age

B. IV
Immigrant share
0.027
(0.011)
0.019
(0.013)
Log years of schooling
---
$-1.497$
(1.042)
Percent prime age
0.299
(1.128)
$-0.007$
(0.005)

$\begin{array}{cc}(0.005) & (0.005) \\ --- & 0.920 \\ & (0.526) \\ --- & 1.091 \\ & (0.715)\end{array}$
Notes: Standard errors reported in parentheses and clustered at the state level. All regressions include state and year fixed effects. The pre-2000 GSP data was obtained from usgovernmentspending.com, and the post- 1997 data from the Bureau of Economic Analysis. The immigrant share was calculated using data from the 1960-2000 decennial censuses and the 2010 and 2017 American Community Surveys. The mean schooling and prime-age variables are calculated in the sample of native workers. The IV regressions use the 1960 census to construct an instrument based on the geographic settlement of immigrants at that time (within each national origin group); see text for additional details. The OLS regressions have 350 observations, and

\begin{tabular}{cccc}
\multicolumn{2}{c}{ Log GSP } & \multicolumn{2}{c}{ Log per-capita GSP } \\
\hline$(1)$ & $(2)$ & $(1)$ & $(2)$ \\
\hline & & & \\
0.032 & 0.031 & -0.002 & -0.000 \\
$0.008)$ & $(0.008)$ & $(0.005)$ & $(0.003)$ \\
--- & -0.702 & --- & 1.358 \\
& $(0.745)$ & & $(0.302)$ \\
--- & -0.045 & --- & 1.113 \\
& $(1.317)$ & & $0.743)$
\end{tabular}
the IV regressions have 300 observations. 
Table 2. The short-run immigration surplus, 2017

Immigration surplus

Loss to native workers

Gain to native firms

Total increase in GDP

Payments to immigrants
In billions of dollars

56.4

566.9

623.3

$2,322.3$

$2,265.9$

Source: Updated from Borjas (1995). The calculation assume that labor's share of income is 0.7 and that the immigrant share of the workforce is 16.6 percent. The value of GDP in 2017 was \$19.5 trillion. 


\section{Table 3. Estimates of the wage elasticity}

\begin{tabular}{lcl} 
Study & Elasticity & Native sample \\
Llull (2015) & -1.7 & Men \\
Altonji and Card (1991) & -1.7 & $\begin{array}{l}\text { Dropouts, black men } \\
\text { Dropouts }\end{array}$ \\
Borjas (2016b) & -1.0 & $\begin{array}{l}\text { Dropouts, non-Hispanic men } \\
\text { Dropouts, non-Hispanic men }\end{array}$ \\
Monras (2015) & -1.4 & High school graduates or less, non-Hispanic \\
Borjas (2003) & -0.5 & Men \\
Cortes (2008) & -0.6 & Dropouts, Hispanic with poor English \\
& -0.6 & Dropouts, Hispanic \\
Card and Peri (2016) & -0.3 & Dropouts \\
Card (2001) & -0.1 & Men \\
Peri and Yasenov (2015) & -0.2 & Men \\
M & -0.1 & Men \\
\hline
\end{tabular}

Source: Blau and Mackie (2016), Table 5-2, p. 242. See the NAS report for detailed citations to the studies included in the table. 
Table 4. Simulated percent wage effects of 1990-2010 immigrant supply shock on native workers

Percent supply shift

Basic simulation:

Short run

Long run
$-6.3$

$-3.1$

$-2.8$

0.4

$-2.3$

$-3.3$

$-0.1$

0.9

$-1$
College Post-

All Dropouts Graduates College Graduates College Natives

Similar immigrants and natives are complements:

Short run

Long run

And high school dropouts and high school graduates are perfect substitutes:

\section{Short run}

Long run
$-1.7$

$-2.3$

0.9

$-2.0$

1.2

$-2.7$

0.5

$-3.3 \quad-2.6$

$-0.1 \quad 0.6$

Source: Blau and Mackie (2016), Table 5-1, pp. 236-237. The simulation results that assume statistically similar immigrants and natives are complements assume an elasticity of substitution between the two groups equal to 20. 


\section{Table 5. Long-run fiscal impact of immigration}

\begin{tabular}{lrr} 
& $\begin{array}{c}\text { Future path of taxes and } \\
\text { spending projected by } \\
\text { the CBO }\end{array}$ & $\begin{array}{c}\text { Current path of taxes } \\
\text { and spending continues } \\
\text { into future }\end{array}$ \\
\cline { 2 - 3 } $\begin{array}{l}\text { Marginal cost pricing for } \\
\text { public goods }\end{array}$ & \\
All workers & $+\$ 58,000$ & $-\$ 36,000$ \\
High school dropouts & $-196,000$ & $-219,000$ \\
High school graduates & $-47,000$ & $-112,000$ \\
Some college & 99,000 & $-10,000$ \\
Bachelor's degree & 280,000 & 123,000 \\
Graduate education & 547,000 & 318,000 \\
Average cost pricing for & & \\
public goods & & $-\$ 119,000$ \\
All workers & $-\$ 5,000$ & $-301,000$ \\
High school dropouts & $-259,000$ & $-193,000$ \\
High school graduates & $-109,000$ & $-96,000$ \\
Some college & 34,000 & 39,000 \\
Bachelor's degree & 216,000 & 236,000 \\
Graduate education & 485,000 &
\end{tabular}

Source: Blau and Mackie (2016), Table 8-12, pp. 430-433. All estimates are in 2013 dollars. 